\title{
Tekelan Leaves (Chromolaena odorata) Infusion and $10 \%$ Povidone-Iodine on Incision Wound Healing Process of Mice (Mus musculus) Infected with Staphylococcus aureus
}

\author{
Arif Caesar Budi ${ }^{1}$, Iwan Sahrial Hamid ${ }^{1 *}$, and Djoko Legowo ${ }^{2}$ \\ ${ }^{\prime}$ Department of Veterinary Basic Medicine, Faculty of Veterinary Medicine, Universitas Airlangga, Surabaya-60115, Indonesia \\ ${ }^{2}$ Department of Veterinary Pathology, Faculty of Veterinary Medicine, Universitas Airlangga, Surabaya-60115, Indonesia \\ *Corresponding author's Email: kelana_dawley68@yahoo.com; (D) ORCiD: 0000-0001-6786-7491
}

\begin{abstract}
Skin is considered to be the most prone organ to injury and infection compared to other body organs. Skin infections are most commonly caused by Staphylococcus aureus. The most commonly used synthetic drugs to overcome skin problems is Povidone-iodine. Considering the Indonesian traditional method, injuries could be cured by dripping Tekelan leaves (Chromolaena odorata) infusion on the wounded skin area. This study aimed to compare the treatment effects of Tekelan leaves (Chromolaena odorata) infusion and povidone-iodine in the wound healing process of mice skin. The subjects of this study were 25 mice (Mus musculus) which were incised and infected with Staphylococcus aureus in 5 groups, namely, P0 (without treatment), P1 (povidone-iodine 10\%), P2 (Tekelan infusion 5\%), P3 (Tekelan infusion 10\%), and P4 (Tekelan infusion 20\%). Observations were made microscopically on wound conditions based on a total assessment of the four observed parameters (epithelization, inflammation rate, connective tissue proliferation, and angiogenesis). The results showed that the total observation value in the P0 and P2 groups was lower than the other groups. The P1 group obtained the highest score. The Kruskal-Wallis test showed a significant difference among the treatment groups $(\mathrm{p}<0.05)$. While the Mann Whitney test indicated P1 had a significant difference with P0, P2, and P3, it had no significant difference with P4. It can be concluded that the Tekelan Leaves (Chromolaena odorata) infusion can be used as an alternative of povidone-iodine with an optimal concentration of $20 \%$.
\end{abstract}

Keywords: Chromolaena odorata, Histopathology, Povidone-iodine, Skin, Wound healing

\section{INTRODUCTION}

Skin protects the organs and underlying tissues of a human body from the environmental harms, including ultraviolet radiation, chemicals, allergens, and microorganisms. The skin also plays a pivotal role in the process of homeostasis by regulating body temperature and blood pressure. Skin as an organ that interacts directly with the environment often experiences injuries induced by surgery, burns, and accidents. Skin can become infected during the process of healing, through which a microorganism enters the body and multiplies. The infection itself can be caused by a variety of factors, including bacteria, viruses, fungi, and parasites. In fact, all open wounds contain and are contaminated with different levels of bacteria until successful wound closure has been accomplished (Hamer et al., 1975). One of the bacteria that often cause wound infections in the skin is Staphylococcus aureus.

Staphylococcus aureus is a flora normally found on the skin. Staphylococcus aureus infection can be transmitted directly through the mucous membranes that are in contact with the skin leading to festered inflammation (Jawetz et al., 2013). Synthetic drugs that contain various chemicals to treat wound infections have been developed and are available in the market. However, these costly synthetic drugs have side effects and can harm vital organs since they can be toxic. One of the most frequent examples of synthetic drugs used in wound healing, especially on the skin, is povidone-iodine (Sammartino et al., 2012). This antiseptic is considered a safe alternative to antibiotics for surgeries with a high risk of wound infection induced by operative bacterial contamination (Gilmore et al., 1997). Therefore, Chromolaena odorata (Tekelan) is regarded as an inexpensive and efficient alternative substitute with fewer side effects and a lower level of toxicity.

Chromolaena odorata is a kind of weed that quickly groves and covers open areas, such as plantations. The herbicides that are used in the extermination of this weed can cause pollution in the soil and the surrounding environment (Mugwedi, 2020). Although this plant causes problems, inhabitants of some regions in Indonesia (e.g., Aceh) have traditionally been accustomed to using the Tekelan leaves to treat diabetes and skin sores. Tekelan leaves have also been applied traditionally in Vietnam and several other tropical countries to treat leech bites, soft tissue injuries, burns, and skin infections. The infusion is extracted by squeezing young leaves until they break, and the resulting liquid is used to treat skin sores (Marianne et al., 2014). Tekelan leaves can be used as malaria or jaundice treatment or an antipyretic 
agent (Vital and Rivera, 2009) since they have antibacterial, antifungal, and antiprotozoal effects (Atindehou et al., 2013).

Tekelan leaves contain flavonoids, saponins, and tannins (Ngozi et al., 2009). Flavonoid compounds are known to function as antibacterial, antifungal, antiviral, and anti-inflammatory agents. Saponin stimulates the formation of collagen which is a structural protein playing a role in the process of wound healing. Saponin as well as tannin has an antibacterial function. With this background in mind, it is necessary to conduct a comparative study on the histopathological differences induced by the effects of Tekelan leaves (Chromolaena odorata) infusion and povidoneiodine on mice (Mus musculus) infected with Staphylococcus aureus. In addition, the present study sought to determine the optimal concentration of Tekelan leaves infusion by analyzing the obtained score of each method.

\section{MATERIALS AND METHODS}

\section{Materials}

Tekelan leaves (Chromolaena odorata) obtained from the slopes of Mount Penanggungan, Pasuruan, East Java were used in the current study. Povidone-iodine $10 \%$ was used as a comparison benchmark in wound healing tests. Ketamine was administered as an anesthetic drug. Staphylococcus aureus was used as an infectious agent. Polyzwitterions (PZ) was utilized as a bacterial suspension material which could improve the antibiofouling properties of membrane surfaces. $\mathrm{H} 2 \mathrm{SO} 4$ and $\mathrm{BaCl} 2$ were used as raw material for McFarland's solution. Mannitol Salt Agar was used as a medium for bacterial propagation. Bacterial identification test was performed using the following materials: carbol gentian violet, Lugol, H2O2, safranin, acetone alcohol, emersion oil, 70\% ethanol, and rabbit blood plasma. Fish pellets were used as mice feed. Other materials used in the preparation of histopathological consisted of HaematoxylinEosin dyes, alcohol, xylol, paraffin, and $10 \%$ formalin.

\section{Animal}

The sample in this study consisted of 25 white male mice BALB/c, aged 1.5-2 months old with a weight of 25-30 grams obtained from the Farm Veterinary Center in Surabaya. Staphylococcus aureus bacteria was used as an agent model to infect incision wounds obtained from the Veterinary Bacteriology and Mycology Laboratory, Faculty of Veterinary Medicine, Universitas Airlangga, Surabaya, Indonesia.

\section{Making Tekelan Leaves Simplisia}

Tekelan leaves (Chromolaena odorata) simplisia was made by drying the leaves at a moderately high temperature to eliminate the possibility of changes in active ingredient compounds. The followed stages included raw material collection, wet sorting, washing, and drying without direct sunlight (DepKes, 1995).

\section{Manufacture of Tekelan Leaves Infusion}

Tekelan leaves infusion was made with a concentration of $5 \%, 10 \%$, and $20 \%$. The $20 \%$ infusion was prepared using 20 grams of Tekelan leaves simplisia put into the pan with $100 \mathrm{ml}$ of water and heated 15 minutes. When it reached $90^{\circ} \mathrm{C}$, the mixture was occasionally stirred. The extract was filtered using flannel cloth while it was still hot. In case the volume of water reached below $100 \mathrm{ml}$, hot water was added in the pulp to obtain the volume of $100 \mathrm{ml}$ (DepKes, 1995). The concentration of $10 \%$ and dilution of $5 \%$ was obtained from the infusion of $20 \%$ concentration.

\section{Clinical Trials}

\section{Adaptation of Experimental Animals}

Before the initiation of the study, all mice were adapted to the environment for \pm 7 days to control their health conditions. The daily feeding system of experimental animals was the same. All 25 mice were divided into 5 treatment groups while each treatment group contained 5 mice. The group that received no treatment was set as a negative control (P0), Povidone-iodine $10 \%$ group was considered as a positive control (P1), infusion treatment groups 5\% as $\mathrm{P} 2$, $10 \%$ as P3, and finally, $20 \%$ as P4. The mice were weighed after the adaptation period. The adaptation of experimental animals was carried out in experimental animal cages of Veterinary Medicine Faculty, Universitas Airlangga.

\section{Suspension of Staphylococcus aureus}

Some bacterial colonies Staphylococcus aureus obtained from the Bacteriology and Mycology Laboratory of the Faculty of Veterinary Medicine, Universitas Airlangga were bred to the media Mannitol Salt Agar (MSA) and incubated at $37^{\circ} \mathrm{C}$ for 24 hours. Afterwards, identification was carried out to the species stage, namely rejuvenation on MSA 
media, gram staining, and catalase test up to coagulase test. Furthermore, the suspension was made by taking several colonies of Staphylococcus aureus to be put into a test tube that contains $10 \mathrm{ml}$ of PZ.

\section{Staphylococcus aureus Dose}

The lowest score for $100 \%$ infecting experimental animals was obtained by comparing the density of the colony suspension Staphylococcus aureus with McFarland concentration on number 1 ( $3 \times 108$ cells/ml), following that a 10-2 series dilution was made by taking $1 \mathrm{ml}$ from the previous tube into $9 \mathrm{ml} \mathrm{PZ}$ to obtain a bacterial count of $3 \times 106$ cells/ml. (Umar et al., 2012)

\section{Experimental Animal Treatment}

After the experimental animals were adapted, 25 mice (Mus musculus) were first anesthetized by ketamine with a dose of $40 \mathrm{mg} / \mathrm{kg}$ body weight for each mouse. In the next step, the fur of the wound section was shaved. In order to make the wound, the mice were incised on the musculus gluteus medius of the right hand using a scalpel of $1 \mathrm{~cm}$ long and $2 \mathrm{~mm}$ deep. In the next step, the skin was stretched with the index finger and thumb of the left hand, acting as stretchers and presses. Scalpel held by the right hand formed an angle of 30-40 degrees on the skin. The incision was made by dragging the scalpel toward the caudal (Chandra et al., 2018). Afterwards, the wounds were infected using Staphylococcus aureus by dropping the bacterial suspension of $10 \mu \mathrm{l}$ using a micropipette (Umar et al., 2012). All 25 mice were then randomly divided into 5 treatment groups. The P0 treatment group that received treatment was set as the negative control, P1 was given povidone-iodine $10 \%$ as the positive control, $\mathrm{P} 2$ was subjected to Tekelan leaves infusion concentration of 5\%, P3 was treated using Tekelan leaves infusion concentration of 10\%, and P4 was given Tekelan leaves infusion concentration of $20 \%$. Topical treatment was given by dripping with a solution of Tekelan leaves and povidone-iodine $10 \%$ in 1 drop of Pasteur pipette. The treatment was carried out twice a day with a 12-hour interval for ten days. It was started from the second day after the experimental animals were being infected with Staphylococcus aureus. After ten days, euthanization was carried out on mice by cervicalis (breaking joints atlantooccipitalis) dislocation. Finally, the skin area was taken to sample the wound for the preparation of histopathological preparations.

\section{Experimental Design}

This research was conducted during March 2017. The research process was carried out in the Bacteriology and Mycology Laboratory as well as the Experimental Animals Quarantine of the Faculty of Veterinary Medicine, Universitas Airlangga, Campus C, Mulyorejo, Surabaya. This research was an experimental study in a laboratory with a completely randomized design (CRD) since there was only one source of diversity, namely the treatment that was discriminated against in addition to random influences (Kusriningrum, 2008). Table 1 shows the scoring details of each observed parameter.

Table 1. Score on each parameter in wound healing process of Mice

\begin{tabular}{|c|c|c|}
\hline Parameters & Treatment & Description \\
\hline \multirow{5}{*}{ Epithelialization } & Score 0 & No epithelialization occurs \\
\hline & Score 1 & Epithelium formed $(0-25 \%)$ \\
\hline & Score 2 & Epithelium formed (25-50\%) \\
\hline & Score 3 & Epithelium formed (50-75\%) \\
\hline & Score 4 & Epithelium formed (75-100\%) \\
\hline \multirow{5}{*}{$\begin{array}{l}\text { The level of inflammation is based on the number of } \\
\text { inflammatory cells in the five fields of view at a magnification } \\
\text { of } 1000\end{array}$} & Score 0 & More than 100 \\
\hline & Score 1 & $75-100$ \\
\hline & Score 2 & $50-75$ \\
\hline & Score 3 & $25-50$ \\
\hline & Score 4 & Less than 25 \\
\hline \multirow{5}{*}{$\begin{array}{l}\text { Proliferation of connective tissue is based on comparison of } \\
\text { the number of fibroblasts in the wound area with normal areas }\end{array}$} & Score 0 & 5 times normal tissue \\
\hline & Score 1 & 4 times the normal tissue \\
\hline & Score 2 & 3 times the normal tissue \\
\hline & Score 3 & 2 times the normal tissue \\
\hline & Score 4 & $\begin{array}{l}\text { equal or less than } 2 \text { times of the normal } \\
\text { network }\end{array}$ \\
\hline \multirow{5}{*}{$\begin{array}{l}\text { Angiogenesis is based on a comparison between the number of } \\
\text { blood vessels that form in the wound and the normal area }\end{array}$} & Score 0 & 5 times normal tissue \\
\hline & Score 1 & 4 times the normal tissue \\
\hline & Score 2 & 3 times the normal tissue \\
\hline & Score 3 & 2 times the normal tissue \\
\hline & Score 4 & $\begin{array}{l}\text { equal or less than } 2 \text { times of the normal } \\
\text { network }\end{array}$ \\
\hline
\end{tabular}




\section{Experimental design}

The examination was carried out by observing the histopathological picture of five treatments with each of five replications on the microscope addressing four parameters of epithelialization, level of inflammation, proliferation of connective tissue, and angiogenesis (Greenhalgh et al., 1990). Statistical method was based on ANOVA method, and completely randomized design (CRD) was conducted. Observations were based on four parameters in five treatments; starting from the first observation of the incised wound area then being shifted 9 twice to the left and twice to the right horizontally. Then a score of zero to four is performed according to the results of microscopic observations on each parameter observed and totaled.

\section{Data Analysis}

The data on the healing property of Tekelan leaves infusion on mice incision wound that was infected with Staphylococcus aureus was obtained from the wound healing value of each treatment group. The data were analyzed statistically using the Kruskal-Wallis proceeded with the Mann Whitney test. P-value less than 0.05 was considered statistically significant. Statistical analysis was performed using the SPSS software, version 20.

\section{RESULTS}

The obtained results of the Kruskal-Wallis test indicated that H0 was rejected $(\mathrm{p}=0.009)$ and H1 was accepted. This means that there was a histopathological difference in the skin between the administrations of Tekelan leaves (Chromolaena odorata) infused with povidone-iodine $10 \%$ in the mice (Mus musculus) infected with Staphylococcus aureus. To find out more about the differences between the treatment groups and povidone-iodine groups, the Mann Whitney Test was performed later. The findings of the Mann Whitney test revealed that P1 significantly differed from P0 and P2 ( $\mathrm{p}=0.009)$. Likewise, there was a significant difference between P1 and P3 ( $\mathrm{p}=0.007)$. However, the comparison of P1 and P4 indicated that there was no significant difference. Table 2 indicated the results of the average and standard deviation. Based on Table 2 the highest average values were for the treatment groups of P1, P3, and P4 with the mean values of 12.80, 10.20, 11.20, respectively. The P2 and P0 treatment groups means of 9.40 and 9.20 had the lowest value. Table 1 reveals the significant difference between $\mathrm{P} 1$ and the treatment groups of P0, P2, P3, and P4.

Table 2. Mean and standard deviation of histopathological score of the skin

\begin{tabular}{lc}
\hline Treatment group & Skin histopathological score $(\mathbf{X} \pm$ SD) \\
\hline P0 (without treatment) & $9.20 \pm 1.92^{\mathrm{a}}$ \\
P1 (Povidone-iodine 10\%) & $12.80 \pm 0.45^{\mathrm{b}}$ \\
P2 (Tekelan Infusion 5\%) & $9.40 \pm 1.82^{\mathrm{a}}$ \\
P3 (Tekelan Infusion 10\%) & $10.20 \pm 0.84^{\mathrm{a}}$ \\
P4 (Tekelan Infusion 20\%) & $11.20 \pm 1.30^{\mathrm{ab}}$ \\
\hline
\end{tabular}

Note: Different superscripts in the same column show ba significant difference based on the Mann Whitney test ( $<$ 0.05). X: Mean, SD: Standard deviation.

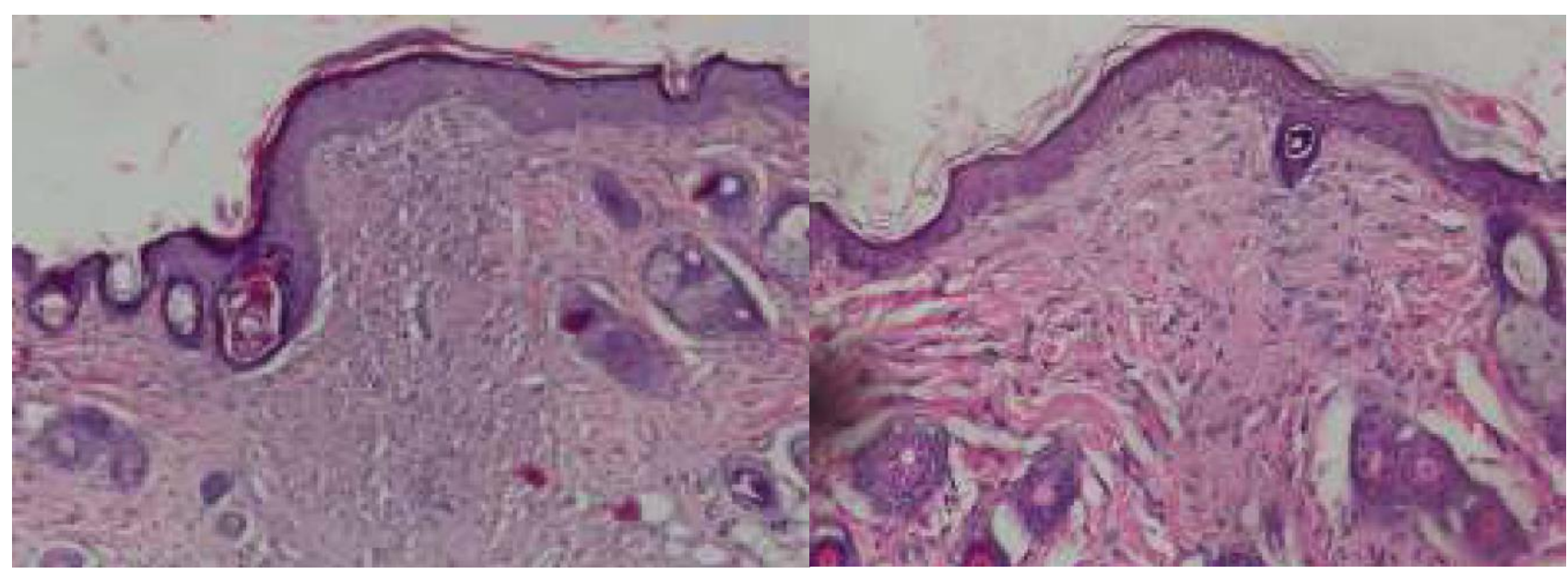

Figure 1. P0 and P1 with a magnification of $100 \mathrm{X}$ in wound healing process of mice (mus musculus) infected with Staphylococcus aureus 


\section{Histopathological description}

Based on microscopic observations of the wound area, the histopathological picture of mice skin for each treatment group indicated closure on the tenth day of epithelialization. The level of inflammation in the treatment group of P0, P2, and P3 was still high, compared to the other groups, and the least was found in the treatment P1. The connective tissue and angiogenesis were also observed in the same order of occurrence. The new capillaries and fibroblasts were found to be quite dense In P0, P2, and P3, compared to other groups and decreased in number in the P4 group. As can be seen in Figure 1, the P1 group was the one with the least new capillaries and had fibroblasts that had begun to lose in contrast to the other treatment groups. In P0 treatment group, there was a marked difference especially in the level of inflammation that appeared to be very dark blue. The color was due to the high number of inflammatory cells and fibroblasts in the healing area and the maturity of the collagen coirs on the edge of the healing area which was red in color and visible on P1.

\section{DISCUSSION}

Concerning the healing process of the investigated samples infected with Staphylococcus aureus, a histopathological difference was observed between the healed skin by the administration of infused Tekelan leaves (Chromolaena odorata) and the one with povidone-iodine $10 \%$. The samples in the P1 group (the administration of povidone-iodine $10 \%$ ) significantly differed from those with no treatment group (P0), 5\% infusion administration (P2), and 10\% infusion administration (P3). The $20 \%$ infusion (P4) showed no significant difference meaning that the administration of povidone-iodine $10 \%$ had better healing values than the other treatment alternatives. Therefore, the P4 group with a concentration of $20 \%$ had the highest value among the other treatment groups that were close to the healing value of povidone-iodine $10 \%$.

The fewest number of inflammatory cells were observed in the histopathological observation of P1. The reason povidone-iodine naturally acts as an antiseptic to kill bacteria by inhibiting bacterial enzyme metabolism and preventing their replication. The reduction of infection in the wound area resulted in a normal wound healing process. In the initial stages of the wound healing process, there was an inflammatory and formation phase of reactive oxygen species (ROS) produced by neutrophils and macrophages as part of the immune system to help speed up wound cleansing. Aside from positive effects, ROS also had a negative impact. It is a toxic byproduct of aerobic metabolism required for many important signaling reactions (Mittler, 2017). Redox biology involved a small increase in ROS levels that activated signaling pathways to initiate biological processes while oxidative stress denoted high levels of ROS resulting in the damage to DNA, proteins, or lipids (Schieber and Chandel, 2014).

Flavonoids as powerful antioxidants can eradicate free radicals to protect the body against ROS, enhance the function of endogenous antioxidants, and increase antioxidant enzymes in granulation tissue (Auf Dem Keller et al., 2006). This can be observed in the treatment group that received the infusion of Tekelan (Chromolaena odorata), especially in P4. In this group, the number of inflammatory cells and fibroblasts was almost the same as in P1. Unlike the other groups, P0, P2, and P3 obtained a higher number of inflammatory cells and fibroblasts. This was due to the differences in the concentrations of $\mathrm{P} 2$ and $\mathrm{P} 3$, and finally in the P0 group which received no treatment leading to the slowest speed of the healing process. The tannin and saponin active substances in Tekelan leaves acted as antimicrobials, increased wound contraction, and epithelialization rate (Thakur et al., 2011). This was evident by the closure of all epithelium in each treatment group that was administered with Tekelan leaves infusion (Chromolaena odorata). Saponins could also increase TGF- $\beta$ receptors in fibroblasts to bind TGF- $\beta$, which was a growth factor needed by fibroblasts in synthesizing collagen (Agarwal et al., 2009). Collagen was an extracellular matrix that acted as a framework for keratinocyte migration. The formation of a denser extracellular matrix would stimulate the process of epithelialization of keratinocytes (Nayak and Pereira, 2006). This could be observed in the group treated with Tekelan leaves (Chromolaena odorata) infusion, where the higher the infusion concentration, fibroblast proliferation occurred more quickly on a high amount, consequently accelerating the synthesis and maturation of collagen.

Tannins played a role in the regulation of transcription and translation of vascular endothelial growth factor (VEGF) (Li et al., 2011). VEGF which acted according to paracrine not only worked on the skin vascular endothelial cells but also on keratinocytes and immune cells that promoted re-epithelialization. Moreover, VEGF stimulated angiogenesis and restored oxygen perfusion (Gogiraju et al., 2019; Olfati and Moradi-kor, 2019). This was evident in the P2 and P3, where a large number of new blood vessels were formed. The number of new blood vessels would continue to decrease in line with the speed of wound healing and granulation tissue maturation based on the amount of Tekelan leaves infusion (Chromolaena odorata) which was seen in the group P4.

The present study substantiated that povidone-iodine $10 \%$ and Tekelan leaves infusion could increase the healing value of incision wounds in mice infected with Staphylococcus aureus based on its concentration. Similarly, the optimal concentration of Tekelan leaves infusion was regarded as $20 \%$. Therefore, in the present study, the concentration of $20 \%$ obtained the highest value and it was close to the value and quality of povidone-iodine $10 \%$. 


\section{CONCLUSION}

The administration of povidone-iodine $10 \%$ could lead to a significant difference compared to $5 \%$ and $10 \%$ Tekelan leaves infusion. The Tekelan leaves infusion with a concentration of $20 \%$ led to no significant difference. To be specific, the optimal concentration of Tekelan leaves infusion in the wound incision healing process of mice (Mus musculus) infected with Staphylococcus aureus was obtained at a concentration of $20 \%$.

\section{DECLERATION}

Author's contribution

Arif Caesar BUDI S., Iwan Sahrial HAMID, and Djoko LEGOWO had similar roles in conduction, writing and editing of manuscript.

\section{Competing interest}

The author did not report any conflicts of interest in the current research.

\section{REFERENCES}

Agarwal PK, Singh A, Gaurav K, Goel S, Khanna HD, and Goel RK (2009). Evaluation of wound healing activity of extracts of plantain banana (Musa sapientum var. paradisiaca) in rats. Indian Journal of Experimental Biology, 47(1): 32-40. PMID: 19317349

Atindehou M, Lagnika L, Guérold B, Strub JM, Zhao M, and Van Dorsselaer A (2013). Isolation and identification of two antibacterial agents from Chromolaena odorata L. active against four diarrheal strains. Advances in Microbiology, 3: 115-121. DOI: http://dx.doi.org/10.4236/aim.2013.31018

Auf Dem Keller U, Kümin A, Braun S, and Werner S (2006). Reactive oxygen species and their detoxification in healing skin wounds. Journal of Investigative Dermatology Symposium Proceedings, 11: 106-111. DOI: https://www.doi.org/10.1038/sj.jidsymp.5650001

Chandra S, Podder I, Chatterjee M, and Field L (2018). Anatomy and applications of the \#15 scalpel blade and its variations. Journal of Cutaneous and Aesthetic Surgery, 11(2): 79-82. DOI: https://www.doi.org/10.4103/JCAS.JCAS_70_16

DepKes RI (1995). Farmakope indonesia edisi IV. Jakarta Dep Kesehat Republik Indones, Departemen Kesehatan RI, Jakarta, pp. 112-115. Availble at: https://bbpombandung.app/bandung.pom.go.id/elibrary/detail_buku_fisik/4

Gilmore OJ, Reid C, and Strokon A (1977). A study of the effect of povidone-iodine on wound healing. Postgraduate Medical Journal, 53(617): 122125. DOI: https://www.dx.doi.org/10.1136\%2Fpgmj.53.617.122

Gogiraju R, Bochenek ML, and Schäfer K (2019). Angiogenic endothelial cell signaling in cardiac hypertrophy and heart Failure. Frontiers in cardiovascular medicine, P. 20. DOI: https://www.doi.org/10.3389/fcvm.2019.00020

Greenhalgh DG, Sprugel KH, Murray MJ, and Ross R (1990). PDGF and FGF stimulate wound healing in the genetically diabetic mouse. The American Journal of Pathology, 136(6): 1235-1246. PMID: 2356856

Hamer ML, Robson MC, Krizek TJ, and Southwick WO (1975). Quantitative bacterial analysis of comparative wound irrigations. Annals of Surgery, 181(6): 819-822. DOI: https://www.dx.doi.org/10.1097\%2F00000658-197506000-00010

Jawetz E, Melnick JL, and Adelberg EA (2013). Medical Microbiology. Springer-Verlag, UK, pp. 117-121. Available at: http://microbiology.sbmu.ac.ir/uploads/jawetz 2013 medical miceobiology.pdf

Kusriningrum RS (2008). Perancangan percobaan. Universitas Airlangga Press. Surabaya, p. 84. Available at: http://library.um.ac.id/freecontents/index.php/buku/detail/perancangan-percobaan-kusriningrum-r-s-33764.html

Li K, Diao Y, Zhang H, Wang S, Zhang Z, and Yu B (2011). Tannin extracts from immature fruits of Terminalia chebula Fructus Retz. promote cutaneous wound healing in rats. BMC Complementary and Alternative Medicine, 11(1): Article number: 86. DOI: https://www.dx.doi.org/10.1186/1472-6882-11-86

Marianne M, Lestari D, Sukandar EY, Kurniati NF, and Nasution R (2014). Antidiabetic Activity of Leaves Ethanol Extract Chromolaena odorata (L.) RM King on Induced Male Mice with Alloxan Monohydrate. Jurnal Natural, 14: 1-4. Avialble at: http://www.jurnal.unsyiah.ac.id/natural/article/view/1382

Mittler R (2017). ROS are good. Trends in Plant Science, 22(1): 11-19. DOI: https://www.doi.org/10.1016/j.tplants.2016.08.002

Mugwedi L (2020). Harnessing Opportunities Provided by the Invasive Chromolaena odorata to Keep It under Control. Sustainability, 12: Article number: 6505. DOI: https://www.doi.org/10.3390/su12166505

Nayak BS, and Pereira LMP (2006). Catharanthus roseus flower extract has wound-healing activity in Sprague Dawley rats. BMC Complementary and Alternative Medicine, 6(1): 41. DOI: https://www.doi.org/10.1186/1472-6882-6-41

Ngozi IM, Jude IC, and Catherine IC (2009). Chemical profile of Chromolaena odorata L (King and Robinson) leaves. Pakistan Journal of Nutrition, 8: 521-524. DOI: https://www.dx.doi.org/10.3923/pjn.2009.521.524v

Olfati A, and Moradi-kor N (2019). The therapeutic effect of statins on survival of patients with gastrointestinal cancer: a Review. International Journal of Advanced Biological and Biomedical Research, $7(3)$ : 191-203. Available http://www.ijabbr.com/article_34662_6432f4ff2c033909462f4efef7176e79.pdf

Sammartino G, Tia M, Tete S, Perillo L, and Trosino O (2012). Adverse reaction to irrigation with povidone-iodine after deep-impacted, lower third molar extraction. Journal of Biological Regulators and Homeostatic Agents, 26(1): 145-149. PMID: 22475107

Schieber M, and Chandel NS (2014). ROS function in redox signaling and oxidative stress. Current Biology, 24(10): 453-462. DOI: https://dx.doi.org/10.1016\%2Fj.cub.2014.03.034

Thakur R, Jain N, Pathak R, and Sandhu SS (2011). Practices in wound healing studies of plants. Evidence-based Complement Alternative Medicine, Article ID: 438056. DOI: https://www.doi.org/10.1155/2011/438056

Umar A, Krihariyani D, and Mutiarawati DT (2012). Pengaruh pemberian ekstrak daun binahong (Anredera cordifolia) terhadap kesembuhan luka infeksi Staphylococcus aureus pada mencit. Jurnal Ilmiah Mahasiswa Veteriner, 2: 68-75. DOI: https://www.doi.org/10.21157/jim\%20vet..v2i1.5655

Vital PG, and Rivera WL (2009). Antimicrobial activity and cytotoxicity of Chromolaena odorata (L. f.) King and Robinson and Uncaria perrottetii (A. Rich) Merr. Extracts. Journal of Medicinal Plant Research, 3(7): 511-518. DOI: https://www.doi.org/10.5897/JMPR.9000160 